\title{
Dialektika Hukum dan Kekuasaan
}

\author{
Salman Luthan
}

\begin{abstract}
The legal essence can be viewed from several perspectives; authority, substance, sociology and reality. Power is an interaction concepts and social interrelation existing in societies, nation, and human beings. The continuing discussion of legal power and authority appear within two pattems of relationship; law is an equivalent to authority, and law is different from authority. The legal symbiotic relation with power results functional relation. Authority has a certain function toward law and vice versa. Power plays a role as an instrument to form, enforce, and execute the law. Law functions to legitimate and justify power.
\end{abstract}

\section{Pendahuluan}

Kekuasaan mempunyai arti penting bagi hukum karena kekuasaan bukan hanya merupakan instrumen pembentukan hukum (law making), tapi juga instrumen penegakan hukum (law enforcement) dalam kehidupan masyarakat. Pembentukan hukum, khususnya undang-undang, dilakukan melalui mekanisme kekuasaan politik dalam lembaga legislatif di mana kepentingan-kepentingan kelompok masyarakat yang saling bertentangan diupayakan untuk dikompromikan guna menghasilkan satu rumusan kaidah-kaidah hukum yang dapat diterima semua pihak. Penegakan hukum merupakan upaya untuk mendorong masyarakat agar menaati aturanaturan hukum yang berlaku (upaya preventif) dan penjatuhan sanksi hukum terhadap kasus-kasus pelanggaran hukum yang terjadi dalam masyarakat (upaya represif).
Hukum juga mempunyai arti penting bagi kekuasaan karena hukum dapat berperan sebagai sarana legalisasi bagi kekuasaan formal lembaga-lembaga negara, unit-unit pemerintahan, dan pejabat negara dan pemerintahan. Legalisasi kekuasaan itu dilakukan melalui penetapan landasan hukum bagi kekuasaan melalui aturan-aturan hukum. Di samping itu, hukum dapat pula berperan mengontrol kekuasaan sehingga pelaksanaannya dapat dipertanggungjawabkan secara legal dan etis.

Dengan demikian terlihat jelas bahwa hukum dan kekuasaan mempunyai hubungan yang sangat erat. Hubungan itu dapat digambarkan seperti satu mata uang dengan dua sisi. Di satu sisi hukum itu adalah kekuasaan atau wewenang legal, dan di sisi yang lain, hukum itu adalah aturan-aturan 
untuk mengatur tingkah laku manusia dalam masyarakat, termasuk tingkah laku para. penyelenggara negara.

Kharakteristik hubungan hukum dan kekuasaan, khususnya dalam hal legalisasi kekuasaan dan penegakan hukum, dijelaskan oleh Mochtar Kusumah Atmaja dalam satu ungkapkan "hukum tanpa kekuasaan adalah angan-angan, dan kekuasaan tanpa hukum adalah kelaliman".' Ungkapan tersebut, pada satu sisi, mengandung arti bahwa kaidahkaidah hukum tidak akan ada manfaatnya jika tidak ditegakkan, dan hukum itu hanya dapat ditegakkan dengan kekuasaan. Pada sisi lain, ungkapan itu bermakna bahwa kekuasaan tanpa landasan hukum adalah kesewenangwenangan.

Permasalahan utamanya adalah tolok ukur legalitas kekuasaan. Apakah setiap kekuasaan yang berdasarkan aturan hukum dapat dikualifikasikan sebagai kekuasaan sah atau legal? Apakah kekuasaan sewenangwenang yang memiliki landasan hukum harus diterima dan ditaati? Apakah kekuasaan yang sewenang-wenang dapat melahirkan hukum yang adil? Apakah efektivitas penegakan hukum bergantung pada legalitas kekuasaan? Apakah kekuasaan legal yang sewenangwenang dapat menegakkan hukum guna mencapai keadilan?

Meskipun hukum mempunyai hubungan yang sangat erat dengan kekuasaan, tapi studi kekuasaan dalam perspektif hukum masih terbatas sehingga konsep-konsep kekuasaan di dalam ilmu hukum tidak begitu berkembang. Dibandingkan dengan studi politik terhadap kekuasaan, studi hukum terhadap kekuasaan jauh tertinggal, sehingga konsep-konsep kekuasaan yang berkembang lebih didominasi oleh pemikiran-pemikiran politik dan sosiologi:"

Kecenderungan studi hukum lebih terfokus kepada aspek hukum sebagai kaidah yang menjadi pedoman tingkah laku. Dalam konteks ini hukum adalah aturan-aturan tingkah laku dalam kehidupan masyarakat yang bersifat memaksa dan bila aturan itu dilanggar akan mendapat reaksi dan sanksi negatif dari negara. Pemahaman hukum dalam konteks kaidah-kaidah berarti memahami hukum sebagai hal yang seharusnya dilakukan (das sollen) dalam kehidupan masyarakat.

Di samping itu, studi hukum memfokuskan diri pula pada pemahaman hukum sebagai realitas sosial (das sein) yang terjadi dalam masyarakat. Hukum sebagai kenyataan dapat diamati melalui hukum yang hidup. dalam masyarakat atau hukum yang dipraktikkan melalui lembaga peradilan (the fiving law), pelanggaran-pelanggaran hukum yang tejadi (perilaku melanggar hukum). dan ketaatan masyarakat kepada hukum (perilaku taat hukum). Dalam kenyataannya hanya hukum yang hidup dan pelanggaran hukum yang banyak dikaji, sedangkan ketaatan kepada hukum tidak dianggap sebagai masalah.

\section{Esensi Kekuasaan dan Hukum}

Kekuasaan merupakan konsep hubungan sosial yang terdapat.dalam kehidupan

Mochtar Kusumaatmadja. Fungsi dan Perkembangan Hukum dalam Pembangunan Nasional. Jakarta: Binacipta. Hlm. 5. 
komunitas, masyarakat, negara, dan umat manusia. Konsep hubungan sosial itu meliputi hubungan personal di antara dua insan yang berinteraksi, hubungan institusional yang bersifat hierarkis, dan hubungan subjek dengan objek yang dikuasainya. Karena kekuasaan memiliki banyak dimensi, maka tidak ada kesepahaman di antara para ahli politik, sosiologi, hukum dan kenegaraan mengenai pengertian kekuasaan.

Max Weber ${ }^{2}$ dalam bukunya Wirtschaft und Gesellschaft (1992) mengemukakan bahwa "kekuasaan adalah kemampuan untuk, dalam suatu hubungan sosial, melaksanakan kemauan sendiri sekalipun mengalami perlawanan, dan apa pun dasar kemampuan ini". Perumusan kekuasaan yang dikemukakan Weber dijadikan dasar perumusan pengertian kekuasaan oleh beberapa pemikir lain misalnya, Strausz$\mathrm{Hupe}^{3}$ mendefinisikan kekuasaan sebagai "kemampuan untuk memaksakan kemauan pada orang lain" Demikian pula pengertian yang dikemukakan oleh C. Wright Mills, ${ }^{4}$ "kekuasaan itu adalah dominasi, yaitu kemampuan untuk melaksanakan kemauan kendatipun orang lain menentang".

Oleh karena itu, Miriam Budiharjo menyimpulkan, sekalipun ada banyak pandangan yang berbeda-beda mengenai kekuasaan, akan tetapi agaknya ada satu inti yang nampak dalam semua perumusan itu, yaitu bahwa kekuasaan dianggap sebagai kemampuan pelaku untuk mempengaruhi tingkah laku pelaku lain sedemikian rupa, sehingga tingkah laku pelaku terakhir menjadi sesuai dengan keinginan dari pelaku yang mempunyai kekuasaan.

Di samping pengertian kekuasaan sebagai kemampuan untuk memaksakan kehendak atau kemauan kepada pihak lain, beberapa pakar mengartikan kekuasaan sebagai kemampuan untuk membatasi tingkah laku pihak lain. Harold D. Laswell. ${ }^{5}$ dan Abraham Kaplan mengatakan, "kekuasaan adalah suatu hubungan di mana seseorang atau kelompok orang dapat menentukan tindakan seseorang atau kelompok lain agar sesuai tujuan dari pihak pertama. Seiring dengan pandangan Laswell dan Kaplan, Van Doorn ${ }^{6}$ mengungkapkan, "kekuasaan adalah kemungkinan untuk membatasi alternatif-altematif bertindak dari seseorang atau suatu kelompok sesuai dengan tujuan dari pihak pertama". R.J. Mokken merumuskan konsep "kekuasaan adalah kemampuan dari pelaku (seseorang atau kelompok atau lembaga) untuk menetapkan secara mutlak atau mengubah (seluruhnya atau sebagiannya) alternatif-

${ }^{2}$ Miriam Budiardjo. 1991. “Aneka Pemikiran Tentang Kuasa Dan Wibawa." Jakarta: Sinar Harapan. Himl. 16. Dikutip dari Max Weber. 1982. Wirtschaft und Geselschaft. Tubingen Mohr. 1982.

3/bid

'Soelaeman Soemardi. "Pendekatan Terhadap Kejahatan Sebagai Suatu Fenomena Sosial." Dalam Miriam Budihardjo. "Aneka Pemikiran Dalam Tentang Kuasa Dan Wibawa." Dikutip dari Robert Strausz-Hupe. 1956. Power and Community. Him. 12 dan 14.

${ }^{5}$ Budihardjo. Op. Cit. HIm. 20.

6/bid. Hilm. 17. 
alternatif bertindak atau alternatif-altematif memilih, yang tersedia bagi pelaku-pelaku lain".

Kekuasaan untuk menetapkan batasan alternatif-alternatif bertindak bagi seseorang atau sekelompok orang dalam kehidupan masyarakat pada dasarnya adalah pembuatan aturan-aturan hukum sebagai aturan main dalam kehidupan masyarakat yang disertai dengan sanksi hukum tertentu untuk menjamin terselenggaranya ketertiban dan ketenteraman dalam hubungan-hubungan sosial. Aturan hukum tersebut merupakan kewajiban setiap anggota masyarakat guna menjamin terselenggaranya ketertiban dan ketenteraman masyarakat. Kekuasaan dalam konteks ini termasuk dalam lingkup kebijakan publik, khususnya kebijakan hukum (legal policy).

Menurut Talcot Parsons, ${ }^{7}$ kekuasaan adalah kemampuan umum untuk menjamin pelaksanaan dari kewajiban-kewajiban yang mengikat oleh unit-unit organisasi kolektif dalam suatu sistem yang merupakan kewajiban-kewajiban yang diakui dengan acuan kepada pencapaian tujuan-tujuan kolektif mereka dan bila ada pengingkaran terhadap kewajiban-kewajiban dapat dikenai oleh sanksi negatif tertentu siapapun yang menegakkannya.

Pengertian kekuasaan yang dikemukakan oleh Parson menitikberatkan kepada kekuasaan publik untuk menegakkan aturanaturan masyarakat yang bersifat memaksa demi pencapaian tujuan masyarakat. Dengan kata lain, penggunaan kekuasaan adalah untuk perlindungan masyarakat. Perlindungan masyarakat terdiri dari perlindungan masyarakat dari kejahatan dan perlindungan masyarakat dari penjahat, dan perlindungan masyarakat dari kekuasaan yang sewenang-wenang.

Selain berarti kemampuan untuk mempengaruhi orang lain dan penetapan alternatif-alternatif bertindak, kekuasaan juga mengandung makna sarana pelaksanaan fungsi-fungsi dalam masyarakat dan atas nama masyarakat. ${ }^{8}$ Pelaksanaan fungsifungsi dalam masyarakat mencakup pelaksanaan fungsi politik, pelaksanaan fungsi ekonomi, pelaksanaan fungsi sosial dan budaya, pelaksanaan fungsi hukum dan pemerintahan, dan pelaksanaan fungsi-fungsi tainnya. Pelaksanaan fungsi itu bertujuan untuk memperlancar interaksi sosial dan penyelenggaraan kehidupan masyarakat.

Untuk keperluan tulisan ini, kekuasaan diartikan sebagai konsep hubungan sosial dominatif yang menggambarkan adanya suatu kekuatan yang dimiliki oleh seseorang atau satu pranata untuk memaksakan kehendaknya kepada orang lain (termasuk pranata lain) yang dilakukan melalui penetapan perintah-perintah atau pembuatan aturan-aturan tingkah laku sehingga orang lain menjadi tunduk dan patuh terhadap perintah-perintah dan aturan-aturan tingkah laku tersebut.

Dalam masyarakat terdapat pelbagai kekuasaan: kekuasaan yang baik dan jahat, kekuasaan fisik (misalnya kekuasaan tentara dan polisi), kekuasaan ekonomi (misalnya modal dan tenaga kerja), dan juga kekuasaan batin manusia dan susila, misalnya kekuasaan

'Talcott parsons. "The Distribution of Power in AmericanSociety." World Politics. Oktober. 1957. Hlm.139. ${ }^{8}$ Talcott Parsons. 1967. Sociological Theory and Modern Society .New York: The Free press. Hlm. 308. 
kepribadian, kekuasaan agama dan gereja, kekuasaan ilmu pengetahuan, kekuasaan perkataan yang diúcapkan dan yang ditulis, kekuasaan kesusilaan dan kekuasaan adat atau kebiasaan, artinya kekuasaan yang dilakukan atas anggota masyarakat oleh pandangan-pandangan yang berlaku dalam masyarakat mengenai apa yang baik dan buruk, patut dan tidak patut, sopan dan tidak sopan. ${ }^{9}$

Pembagian kekuasaan tersebut merupakan pembedaan kekuasaan secara umum. Kekuasaan dapat dibedakan dalam beberapa kelompok. Misalnya kekuasaan negara dan kekuasaan masyarakat. Kekuasaan negara berkaitan dengan otoritas negara sebagai suatu badan yang diberi wewenang oleh masyarakat guna mengatur kehidupannya secara tertib dan damai. Kekuasaan masyarakat adalah kekuatan/ kemampuan masyarakat untuk mengelola dan mengorganisasikan kepentingan individuindividu dan kelompok-kelompok masyarakat yang menjadi anggotanya sehingga interaksi sosial dapat berjalan secara lancar.

Ketidakseimbangan kekuasaan negara dan masyarakat dapat mendorong terjadinya kekuasaan negara hegemonik di mana negara sangat kuat dan masyarakat sangat lemah sehingga tercipta pola hubungan dominatif dan eksploitatif. Negara bukan hanya campur tangan dalam urusan-urusan kenegaraan dan kemasyarakatan. Tetapi negara juga intervensi dalam kehidupan pribadi anggota masyarakat yang sebenamya bukan teritorial kekuasaan negara.
Pembagian kekuasaan yang sering dijadikan acuan dalam studi kekuasaan adalah pembagian kekuasaan yang dikemukakan oleh Max Weber ${ }^{10}$ yang membagi kekuasaan dalam tiga macam wewenang, yaitu tradisional, kharismatik dan rasional-legal. Wewenang tradisional berdasarkan kepercayaan di antara anggota masyarakat bahwa tradiși lama serta kedudukan kekuasaan yang dilandasi oleh tradisi itu, adalah wajar dan patut dihormati. Wewenang kharismatik berdasarkan kepercayaan anggota masyarakat pada kesaktian dan kekuatan mistik atau religius seorang pemimpin. Hitler dan Mao Tse Tung sering dianggap sebagai pemimpin kharismatik, sekalipun tentu mereka juga memiliki unsur wewenang rasional-legal, Wewenang rasional-legal berdasarkan kepercayaan pada tatanan hukum dilandasi kedudukan seorang pemimpin. Ditekankan bukan orangnya akan tetapi aturan-aturan yang mendasari tingkah lakunya.

Mengenai esensi hukum dapat dikemukakan bahwa ada perbedaan pandangan di antara para ahli hukum tentang hukum. Perbedaan pandangan itu dapat dilihat dari pengertian hukum yang mereka kemukakan yang berbeda antara yang satu dengan yang lainnya. Meskipun ada perbedaan pandangan, namun pengertian itu dapat diklasifikasikan dalam empat kelompok

Pertama, ahli hukum yang mengartikan hukum sebagai nilai-nilai. Misalnya, Victor Hugo yang mengartikan hukum sebagai kebenaran dan keadilan. Sejalan dengan

${ }^{9} \mathrm{Karl}$ Olivecrona. 1939. Law as Fact.Copenhagen-London. Hlm. 123.

"OBdihardjo. Op. Cit. Him. 24. 
pengertian tersebut, Grotius ${ }^{11}$ mengemukakan bahwa hukum adalah suatu aturan moral tindakan yang wajib yang merupakan sesuatu yang benar. Pembahasan hukum dalam. konteks nilai-nilai berarti memahami hukum secara filosofis karena nilai-nilai merupakan abstraksi tertinggi dari kaidah-kaidah hukum.

Kedua, ahli hukum yang mengartikan hukum sebagai asas-asas fundamental dalam kehidupan masyarakat Definisi hukum dalam perspektif ini terlihat dalam pandangan Salmond ${ }^{12}$ yang mengatakan "hukum merupakan kumpulan asas-asas yang diakui dan diterapkan oleh negara di dalam peradilan. Dengan perkataan lain, hukum terdiri dari aturan-aturan yang diakui dan dilaksanakan pada pengadilan".

Ketiga, ahli hukum yang mengartikan hukum sebagai kaidah atau aturan tingkah laku dalam kehidupan masyarakat. Misalnya, Vinogradoff ${ }^{13}$ mengartikan hưkum sebagai seperangkat aturan yang diadakan dan dilaksanakan oleh suatu masyarakat dengan -menghormati kebijakan dan pelaksanaan kekuasaan atas setiap manusia dan barang. Pengertian yang sama dikemukakan oleh Kantorowich, hukum adalah suatu kumpulan aturan sosial yang mengatur perilaku lahir dan berdasarkan pertimbangan dapat dibenarkan/ terjemahan sendiri

Keempat, ahli hukum yang mengartikan hukum sebagai kenyataan (das sein) dalam kehidupan masyarakat. Hukum sebagai kenyataan sosial mewujudkan diri dalam bentuk hukum yang hidup (the living law) dalam masyarakat atau dalam bentuk perilaku hukum masyarakat. Perilaku hukum terdiri dari perilaku melanggar hukum (pelanggaran hukum) dan perilaku menaati aturan-aturan hukum.

Perbedaan pandangan di antara ahli hukum bukan hanya mengenai pengertian hukum, tapi juga mengenai hakekat hukum. Perbedaan pandangan mengenai hakekat hukum ini tergambar dari munculnya berbagai mazhab dalam pemikiran hukum. Pertanyaan pokok tentang hakekat hukum berkaitan dengan hukum yang benar, apakah hukum yang benar? Jawaban atas pertanyaan prinsipil tersebut beraneka ragam dan saling kontradiktif.

Dalam paham hukum agama yang teistik, hakekat hukum adalah perintah Allah. Hukum yang benar adalah hukum yang difirmankan dan diperintahkan oleh Tuhan, pencipta alam semesta. Menurut doktrin Islam, hukum yang benar adalah hukum-hukum Allah yang dirumuskan dalam Qur'an, dan hukum-hukum yang disabdakan Rasul dalam hadist. Sedangkan bagi paham sekuler, hakekat hukum tidak ada hubungannya dengan urusan keagamaan dan ketuhanan, tapi merupakan urusan peradilan, kemasyarakatan, dan kenegaraan.

Dalam konteks ini hakekat hukum bisa ditinjau dari empat perspektif, yaitu perspektif otoritas (wewenang), perspektif substantif, perspektif sosiologis, dan perspektif realis.

"Ahmad Ali. 1996. Menguak Tabir Hukum. Jakarta: Chandra Pratama. HIm. 39.

'2L.B. Curzon. 1979. Jurisprudence. M\&E Handbook. Hlm. 24.

${ }^{13}$ Ali. Op. Cit. HIm. 34. 
Perspektif otoritas merupakan. pandangan paham positivisme yang menempatkan keabsahan huküm pada otoritas pembentukan dan penegakan hukum. Menurut positivisme, hukum adalah perintah penguasa yang berdaulat dalam mengorganisasikan kehidupan masyarakat dan negara dan harus ditaati oleh masyarakat.

Pemikir positivisme yang cukup berpengaruh, John Austin" mengemukakan bahwa hukum adalah seperangkat perintah, baik langsung ataupun tidak langsung, dari pihak yang berkuasa kepada warga masyarakatnya yang merupakan masyarakat politik yang independen, di mana otoritasnya (pihak yaing berkuasa) merupakan otoritas tertinggi). Definisi yang hampir sama dikemukakan pula oleh Blackstone (Abad XVIII) yang mengungkapkan bahwa hukum adalah suatu aturan tindakan-tindakan yang ditentukan oleh orang-orang yang berkuasa bagi orang-orang yang dikuasai, untuk ditaati.

Berbeda dengan perspektif otoritas, perspektif substantif tidak melihat keabsahan hukum dari sudut otoritas yang membentuk hukum tersebut, tapi dari muatan atau isi yang terkandung dalam kaidah-kaidah hukum tersebut. Pandangan perspektif ini tergambar dari pandangan John Locke yang mengemukakan bahwa hukum adalah sesuatu yang ditentukan oleh warga masyarakat pada umumnya tentang tindakantindakan mereka, untuk menilai mana yang merupakan perbuatan yang jujur dan mana yang merupakan perbuatan yang curang.
Perspektif historis meninjau keabsahan hukum kebudayaan masyarakat itu, khusușnya dalam jiwa rakyat. Von Savigny yang menjadi dipelopor perspektif menggambarkan bahwa keseluruhan hukum sungguh-sungguh terbentuk melalui kebiasaan dan perasaan kerakyatan, yaitu melalui pengoperasian kekuasaan secara diam-diam. Hukum berakar pada sejarah manusia, di mana akarnya' dihidupkan oleh kesadaran, keyakinan dan kebiasaan warga masyarakat.

Perspektif sosiologis meninjau keabsahan hukum itu dari sudut kemampuan atau daya kerja hukum mengatur kehidupan masyarakat. Pertanyaan pokoknya adalah, apakah hukum itu dapat berlaku secara efektif untuk mengatur kehidupan masyarakat. Hakekat hukum menurut perspektif sosiologis adalah hukum yang sesuai dengan fakta-fakta sosial. Lundstedt mengemukakan hukum sungguhsungguh berwujud eksistensi dari fakta-fakta sosial, yang secara keseluruhan berbeda dari sekedar ilusi. Hukum adalah esensial jika masyarakatnya bertahan lama, inilah hal yang mendasar dari hukum, oleh karena itu, sangat dibutuhkan kesejahteraan masyarakat.

Kaum realis dapat digolongkan ke dalam perspektif sosiologis karena sama-sama berpijak pada realitas sosial, Hakekat hukum menurut pandangan realisisme adalah hukum yang hidup, yaitu hukum yang dipraktikkan oleh pengadilan dalam menyelesaikan sengketasengketa dan kasus-kasus hukum yang terjadi dalam masyarakat. Holmes, ${ }^{15}$ seorang hakim agung USA yang menjadi pendiri aliran realis,

\footnotetext{
14/bid. HIm. 40.

${ }^{15}$ Curzon. Op. Cit. Hilm. 27.
} 
berpendapat "apa yang diramalkan akan diputuskan oleh pengadilan, itulah yang saya artikan sebagai hukum" Pendapat Holmes ini sejalan dengan pandangan Llewellyn yang menyatakan bahwa apa yang diputuskan oleh seorang hakim tentang suatu persengketaan, adalah hukum itu sendiri.

\section{Hubungan Hukum dengan Kekuasaan}

Pola hubungan hukum dengan kekuasaan ada dua macam. Pertama, hukum adalah kekuasaän itu sendiri. Menurut Lassalle dalam pidatonya yang termashur Uber Verfassungswessen, "konstitusi sesuatu negara bukanlah undang-undang dasar tertulis yang hanya merupakan "secarik kertas", melainkan hubungan-hubungankekuasaan yang nyata dalam suatu negara"16 Pendapat Lassalle ini memandang konstitusi dari sudut kekuasaan. .

Dari sudut kekuasaan, aturan-aturan hukum yang tertuang dalam konstitusi suatu negara merupakan deskripsi struktur kekuasaan yang terdapat dalam negara tersebut dan hubungan-hubungan kekuasaan di antara lembaga-lembaga negara. Dengan demikian, aturan-aturan hukum yang termuat dalam Undang-Undang Dasar (UUD) 1945 merupakan deskripsi struktur kekuasaan ketatanegaraan Indonesia dan hubunganhubungan kekuasaan antara lembagalembaga negara.

Struktur kekuasaan menurut UUD 1945 menempatkan MPR (Majelis Permusyawaratan
Rakyat) dalam hierarki kekuasaan tertinggi. Hierarki kekuasaan di bawah MPR adalah kekuasaan lembaga-lembaga tinggi negara, yaitu presiden, DPR (Dewan Perwakilan Rakyat), DPA (Dewan Pertimbangan Agung), MA (Mahkamah Agung) dan BPK (Badan Pemeriksa Keuangan). UUD 1945 juga mendeskripsikan struktur kekuasan pusat dan daerah. Di samping itu, juga dideskripsikan hubungan kekuasaan antara kekuasaan lembaga tertinggi negara dengan kekuasaan lembaga-lembaga tinggi negara, hubungan kekuasaan di antara lembaga-lembaga tinggi negara, dan hubungan kekuasaan antara pusat dan daerah.

Pemahaman konstitusi dari sudut kekuasaan mempunyai perbedaan dengan pemahaman konstitusi sebagai aturan dasar negara (staats fundamental noms) atau noma dasar (ground norm) negara sebagaimana konsep Hans Kelsen. Kajian hukum, termasuk konstitusi, yang banyak dilakukan adalah kajian normatif, yaitu memahami hukum sebagai aturan tingkah laku.

Hakekat hukum dalam konteks kekuasaan menurut Karl Olivecrona tak lain daripada "kekuatan yang terorganisasi", hukum adalah "seperangkat aturan mengenai penggunaan kekuatan", dia mengingatkan "kekerasan fisik atau pemaksaan" sebagai demikian sama sekali tidak berbeda dari kekerasan yang dilakukan pencuri-pencuri dan pembunuhpembunuh. ${ }^{17}$

Walaupun kekuasaan itu adalah hukum, namun kekuasaan tidak identik dengan

${ }^{16} \mathrm{~L} . J$. van Apeldorn. 1986. Pengantar Ilmu Hukum. Jakarta: PT Pradnya Paramita. Hilm. 70.

${ }^{17}$ Karl Olivecrona. 1939. Law as Fact. Copenhagen-London. HIm. 123, 169. 
hukum. Mengenai hal ini Van Apeldorn mengemukakan bahwa hukum adalah kekuasaan. Hal ini tidak berarti bahwa hukum tidak lain daripada kekuasaan belaka; tidak berarti bahwa hukum dan kekuasaan adalah dua perkataan yang sama. Hukum adalah kekuasaan, akan tetapi kekuasaan tidak selamanya hukum. Might is not right, kata pepatah Inggris yang terkenal. Pencuri berkuasa atas barang yang dicurinya, akan tetapi belum berarti bahwa ia berhak atas barang itu. ${ }^{18}$

Esensi kekuasaan yang sama dengan hukum tersebut menurut Lassalle adalah kekuasaan fisik, khususnya kekuasaan tentara dan polisi. Namun menurut van Apeldorn, kekuasaan fisik (materiil) itu bukanlah anasir yang hakiki dari hukum, apalagi anasir yang esensial daripadanya. Kekuasaan fisik itu biasanya hanya menjadi unsur tambahan: sesuatu accesoir, bukan bagian dari hukum. Sebaliknya kekuasaan susila adalah anasir yang esensial dari hukum, yakni kekuasaan yang diperoleh kaidah-kaidah hukum dari nilai yang diberikan oleh masyarakat padanya, dan berdasarkan hal mana biasanya kaidahkaidah itu dapat mengharapkan pentaatan dengan sukarela oleh anggota-anggota masyarakat. ${ }^{19}$

Kekuasaan fisik adalah kekuasaan yang mengandalkan diri pada kekerasan atau paksaan untuk memaksa ketaatan masyarakat kepada aturan hukum yang berlaku dan bila melanggar akan dikenakan sanksi hukum. Kepatuhan masyarakat kepada hukum sangat ditentukan oleh kualitas aparatur pemaksa (polisi dan jaksa) dalam menjalankan tugasnya. Sedangkan kesusilaan adalah kekuasaan batin yang bersumber kepada kesadaran diri manusia mengenai kebaikan, kepatutan dan rasa keadilan. Kepatuhan masyarakat kepada aturan hukum bukan karena ada paksaan dari aparat penegak hukum, tapi berdasarkan kesadaran diri anggota masyarakat yang dengan sukarela mematuhi aturan-aturan hukum.

Di samping hukum sama dengan kekuasaan, pola hubungan hukum dengan kekuasaan yang lain adalah bahwa hukum tidak sama dengan kekuasaan. Artinya, hukum dan kekuasaan merupakan dua hal yang terpisah. Meskipun hukum dan kekuasaan dua hal yang terpisah, tapi ada hubungan yang erat di antara keduanya. Hubungan itu dapat berupa hubungan dominatif dan hubungan resiprokal (timbal balik). Ada tiga bentuk manifestasi hubungan hukum dan kekuasaan dalam konteks ini.

Pertama, hukum tunduk kepada kekuasaan. Dalam konteks ini hukum bukan hanya menjadi subordinasi kekuasaan, tapi juga sering menjadi alat kekuasaan. Dengan kata lain, kekuasaan memiliki supremasi terhadap hukum atau adanya supremasi kekuasaan. Oleh karena itu, definisi hukum yang dikemukakan oleh para ahli menempatkan hukum berada di bawah kontrol kekuasaan.

Pendapat ahli hukum yang menggambarkan pandangan supremasi kekuasaan terhadap hukum dikemukakan oleh Thrasimachus yang

${ }^{18} \mathrm{lbid}$. Hlm. 69.

rolbid. Hlm. 73. 
mengungkapkan bahwa hukum tak lain daripada apa yang berfaedah bagi orang yang lebih kuat. Pengertian yang hampir sama dikemukakan pula oleh Gumplowicz yang mengungkapkan bahwa hukum bersandar pada penaklukan yang lemah oleh yang lebih kuat; hukum adalah susunan definisi yang dibuat oleh pihak yang kuat untuk mempertahankan kekuasaannya. ${ }^{20}$

Dalam perspektif Marxisme, hukum dibuat tidak untuk melindungi kepentingan seluruh masyarakat, tapi untuk melindungi kepentingan kelompok elit. Hukum adalah alat kaum kapitaslis untuk melindungi kepentingannya dalam melakukan kegiatan bisnis, dan alat penguasa untuk mempertahankan kekuasaannya. Hukum berpihak kepada pihak yang berkuasa dan kaum kapitalis.

Kepentingan dari General Motors adalah kepentingan Amerika Serikat," kata pepatah di negeri Paman Sam. Negara membantu para pengusaha, karena seperti yang diuraikan oleh Poulantzas dan Block, hidup negara ini memang tergantung pada sukses para pengusahanya. Birokrasi negara dibiayai dengan pajak dari mereka. ${ }^{21}$

Kedua, kekuasaan tunduk kepada hukum. Artinya, kekuasaan berada di bawah hukum atau hukum berada di atas kekuasaan, dan hukum yang menentukan eksistensi kekuasaan. Dalam pemikiran hukum, tunduknya kekuasaan kepada hukum merupakan konsep dasar dalam penyelenggaraan ketatanegaraan.
Konsep itu dirumuskan dalam terminologi supremasi hukum (supreme of law).

Supremasi hukum berarti bahwa hukum merupakan kaidah tertinggi untuk mengatur kehidupan bermasyarakat, berbangsa dan bernegara. Hukum sebagai kaidah tertinggi muncul dalam konsep staats fundamental norm atau grund norm menurut pemikiran Hans Kelsen. Di samping itu, supremasi hukum juga berarti bahwa penggunaan kekuasaan untuk menjalankan kehidupan ketatanegaraan dan roda pemerintahan harus berdasarkan kepada aturan hukum. Tanpa landasan hukum, kekuasaan tidak memiliki legalitas.

Pada prinsipnya supremasi hukum tidak lain dari rule of law, sehingga dalam suatu negara hukum tentunya harus terdapat supremasi hukum. Menegakkan supremasi hukum tentunya harus ada rule of law.22 Rule of law suatu konsep yang dipergunakan agar supaya negara dan pemerintahnya, termasuk warga negara tidak melakukan tindakan kecuali berdasarkan hukum.

Timothy O'hogan dalam The End of Law dan A.V. Dicey dalam Law and the Constitution menyebutkan prinsip-prinsip utama negara hukum dalam kaitan tegaknya supremasi hukum. Prinsip-prinsip tersebut meliputi pemerintahan berdasarkan hukum dan menghindarkan kekuasaan yang sewenangwenang, prinsip persamaan dị depan hukum (equality before the law), perlindungan hak asasi manusia (HAM), dan adanya peradilan yang bebas dan independen. ${ }^{23}$

\footnotetext{
20/bid. Him. 70.

${ }^{21}$ Arief Budiman. 1996. Teori Negara, Kekuasaan dan /diologi. Jakarta: Gramedia. HIm. 79.

${ }^{22}$ Harian Kompas. 23 September 1999.

${ }^{23}$ Jawahir Thontowi. "Penegakan Supremasi Hukum dalam Sistem Peradilan Indonesia." Usulan Penelitian.
} HIm. 4 
Ketiga, ada hubungan timbal balik (simbiotik) antara hukum dan kekuasaan. Dalam hal ini hubungan hukum dan kekuasaan tidak bersifat dominatif di mana yang satu dominan atau menjadi faktor determinan terhadap yang lain, tapi hubungan pengaruh mempengaruhi antara keduanya. Hubungan pengaruh mempengaruhi itu bersifat fungsional, artinya hubungan itu dilihat dari sudut fungsi-fungsi tertentu yang dapat dijalankan di antara keduanya. Dengan demikian, kekuasaan memiliki fungsi terhadap hukum, dan sebaliknya hukum mempunyai fungsi terhadap kekuasaan.

\section{Kekuasaan dalam Konteks Hukum}

Kekuasaan dalam konteks hukum berkaitan dengan kekuasaan negara, yaitu kekuasaan untuk mengatur dan menyelenggarakan kehidupan bermasyarakat dan bernegara yang meliputi bidang legislatif, eksekutif dan yudikatif. Pengaturan dan penyelenggaraan kehidupan bermasyarakat dan bernegara itu mencakup pengaturan dan penyelenggaraan di tingkat pusat dan di tingkat daerah. Dengan demikian, kekuasaan merupakan sarana untuk menjalankan fungsi-fungsi pokok kenegaraan guna mencapai tujuan negara.

Menurut Van Vollenhoven ${ }^{24}$ ada empat fungsi pokok kenegaraan yang menjadi tugas negara yaitu: regeling (membuat peraturan) bestuur (pemerintahan dalam arti sempit), rechtspraak (mengadili) dan politie (polisi). Sedangkan menurut Block, ${ }^{25}$ fungsi negara dalam sistem kapitalis ada tiga macam. Pertama, menciptakan kondisi sehingga pengembangan modal bisa berjalan dengan lancar, baik bagi pengusaha nasional maupun asing. Inilah yang disebutnya sebagai business confidence. Kedua, memeratakan kekayaan secukupnya supaya kaum buruh bisa mereproduksikan dirinya, dan juga supaya kaum buruh percaya bahwa mereka sudah diperlakukan secara adil sehingga mereka tidak membuat keributan yang dapat merusak suasana bisnis yang baik. Ketiga, berperan sebagai polisi untuk mencegah gangguan terhadap sistem yang ada, serta mengembangkan suatu ideologi yang membuat kaum buruh merasa diperiakukan adil dalam sistem yang sebenarnya menguntungkan kaum kapitalis.

Struktur kekuasaan negara bersifat hierarkis atau berjenjang, mulai dari kekuasaan tertinggi sampai kekuasaan terendah. Kekuasaan tertinggi dalam suatu negara adalah kedaulatan. Kedaulatan adalah kekuasaan negara secara definitif untuk memastikan aturan-aturan kelakuan dalam wilayahnya, dan tidak ada pihak, baik di dalam maupun di luar negeri, yang harus dimintai izin untuk menetapkan atau melakukan sesuatu. Kedaulatan adalah hak kekuasaan mutlak, tertinggi, tak terbatas, tak tergantung, dan tanpa kecual. ${ }^{26}$

${ }^{24}$ Moh. Kusnardy dan Harmaily Ibrahim. 1988. "Hukum Tata Negara Indonesia." Pusat Studi Hukum Tata Negara UI. HIm. 147. Dikutip dari Van Vollenhoven. Staatsrecht overzee. Op Cit. HIm. 104 - 125, 243.

${ }^{25}$ AriefBudiman. "Bentuk Negara dan Permerataan Hasil Pembangunan". Prisma. Juli 1982.

${ }^{26}$ Magnis Suseno. 1988. Etika Politik. Jakarta: PT Gramedia. Hlm. 53 
Kedaulatan (souvereignity) adalah ciri atau atribut hukum dari negara-negara, dan sebagai atribut negara dia sudah lama ada, bahkan ada yang berpendapat bahwa sovereignity itu mungkin lebih tua dari konsep negara itu sendiri ${ }^{27}$ Dalam teori kenegaraan, ada empat bentuk kedaulatan sebagai pencerminan kekuasaan tertinggi dalam suatu negara. Keempat bentuk kedaulatan itu adalah kedaulatan Tuhan (godsouvereiniteit), kedaulatan negara (staatssouvereiniteit), kedaulatan hukum (rechtssouvereiniteit), dan kedaulatan rakyat (volkssouvereiniteif) ${ }^{28}$

Dalam kedaulatan Tuhan, keabsahan kekuasaan terletak pada sumber kekuasaan yang berasal dari Tuhan. Menurut paham kedaulatan negara, kedaulatan itu ada pada negara, dan dalam kedaulatan hukum, yang berdaulat itu bukan Tuhan dan bukan negara, tapi adalah hukum itu sendiri. Dalam kedaulatan rakyat, yang berdaulat itu adalah rakyat.

Kedaulatan rakyat berarti bahwa yang berdaulat di suatu negara adalah rakyat. Penguasa memperoleh kekuasaan untuk menjalankan fungsi-fungsi kenegaraan (pemerintahan) karena mendapat persetujuan rakyat yang dilakukan melaiui proses pemilihan umum (pemilu). Pemilu merupakan mekanisme demokratis untuk menegakkan prinsip kedaulatan rakyat dalam tatanan kehidupan kenegaraan. Esensi kedaulatan rakyat sama dengan sistem demokrasi. Dengan demikian, negara yang berkedaulatan rakyat adalah negara demokrasi.

Elemen negara demokrasi ada lima macam, yaitu: rakyat terlibat dalam pembuatan keputusan politik, adanya tingkat persamaan kedudukan di antara rakyat; adanya tingkat liberasi dan -kebebasan yang dijamin untuk atau .... oleh rakyat; adanya satu sistem perwakilan, dan satu sistem pemilihan berdasarkan aturan mayoritas. ${ }^{29}$

Bentuk kedua kekuasaan dalam konteks hukum adalah wewenang. Wewenang berasal dari bahasa Jawa yang mempunyai dua arti, yaitu pertama, kuasa (bevoegdheid) atas sesuatu, misalnya atas sebidang tanah, atas suatu hak. Kedua, serangkaian hak yang melekat pada jabatan atau seorang pejabat untuk mengambil tindakan yang diperlukan agar tugas pekerjaan dapat terlaksana dengan baik, kompetensi, yurisdiksi, otoritas. ${ }^{30}$

Adalah ciri khas negara bahwa kekuasaannya memiliki wewenang. Maka kekuasaan negara dapat disebut otoritas atau wewenang. Otoritas atau wewenang adalah "kekuasaan yang dilembagakan", yaitu kekuasaan yang de fakto menguasai, melainkan juga berhak menguasai. Wewenang adalah kekuasaan yang berhak menuntut ketaatan, jadi berhak memberikan perintah. ${ }^{31}$

${ }^{27}$ Fred Iswara. 1964. Pengantar IImu Politik. Dhwiwantara. Hlm. 92.

${ }^{28}$ Sri Soemantri. "Masalah Kedaulatan Rakyat Berdasarkan UUD 1945." Dalam Padmo Wahyono (ed). 1984. Masalah Ketatanegaraan Indonesia Dewasa Ini. Ghalia Indonesia. HIm. 67.

${ }^{29}$ Lyman Tower Sargent. 1984. Contemporary Political Ideologies. Sixth Edition. The Dorsey Press. Hilm. 32-33.

${ }^{30}$ Andi Hamzah. 1986. Kamus Hukum. Ghalia Indonesia. HIm. 633.

${ }^{31}$ Suseno. Op.Cit. HIm. 53. 
Bentuk ketiga kekuasaan dalam hukum adalah hak. Salmond merumuskan hak sebagai kepentingan yang diakui dan dilindungi oleh hukum. Rumusan yang hampir sama dikemukakan oleh Allend yang mengemukakan bahwa hak itu sebagai suatu kekuasaan berdasarkan hukum yang dengannya seorang dapat melaksanakan kepentingannya (the legally guaranteed power to realise an interest). Sedangkan menurut Holland hak itu sebagai kemampuan seseorang untuk mempengaruhi perbuatan atau tindakan seseorang tanpa menggunakan wewenang yang dimilikinya, tetapi didasarkan atas suatu paksaan masyarakat yang terorganisasi ${ }^{32}$

Definisi hak menurut Holmes ${ }^{33}$ adalah nothing but permission to exercise certain natural powers and upon certain conditions to obtain protection, restitution, or compensation by the aid of public force. Hak dapat pula diartikan sebagai kekuasaan yang dipunyai seseorang untuk menuntut pemenuhan kepentingannya yang dilindungi oleh hukum dari orang lain, baik dengan sukarela maupun dengan paksaan.

Dengan mengacu kepada beberapa pengertian tersebut dapat didentifikasikan ciriciri hak. Menurut Fitzgerald, ${ }^{34}$ ciri-ciri yang melekat pada hak adalah:

a. hak itu dilekatkan pada seseorang yang disebut sebagai pemilik atau subjek dari hak itu. la juga disebut sebagai orang yang memiliki titel atas barang yang menjadi sasaran hak. b. Hak itu tertuju pada orang lain, yaitu yang menjadi pemegang kewajiban di mana antara hak dan kewajban terdapat hubungan korelatif.

c. Hak yang ada pada seseorang mewajibkan pihak lain untuk melakukan (monisson) atau tidak melakukan (omission) sesuatu perbuatan. Hal ini dapat disebut sebagai isi dari hak.

d. Perbuatan atau omission itu menyangkut sesuatu yang dapat disebut sebagai objek dari hak.

e. Setiap hak menurut hukum itu mempunyai titel, yaitu suatu peristiwa tertentu yang merupakan alasan melekatnya hak itu pada pemiliknya.

Pengakuan hukum terhadap hak seseorang mengandung konsekuensi adanya kewajiban pada pihak atau orang lain. Hal itu bisa terjadi karena hubungan hak dan kewajiban bersifat resiprokal atau timbal balik hubungan hak dan kewajiban terjadi dalam konsep hubungan hukum, terutama dalam pelaksanaan hubungan hukum (hukum subjektif). Kewajiban adalah suatu perintah hukum yang mengharuskan seseorang untuk memenuhi suatu hal yang menjadi hak orang lain atau melaksanakan perbuatain tertentu.

Dengan deskripsi di atas menjadi jelas bahwa kekuasaan dalam konteks hukum meliputi kedaulatan, wewenang atau otoritas, dan hak. Ketiga bentuk kekuasaan itu memiliki esensi dan ciri-ciri yang berbeda satu sama lain.

32Lili Rasjidi. 1988. Dasar-Dasar Filsafat Hukum. Rajawali. HIm. 45.

${ }^{33}$ Ali. Op. Cit. HIm. 243.

${ }^{34} /$ bid. HIm. 244. 


\section{Fungsi Dialektis Hukum dan Kekuasaan}

Fungsi dialektis hukum dan kekuasaan adalah fungsi timbal balik antara hukum dan kekuasaan. Fungsi hukum dan kekuasaan meliputi fungsi kekuasaan terhadap hukum dan fungsi hukum terhadap kekuasaan. Pembahasan pendahuluan akan mendeskripsikan fungsi kekuasaan terhadap hukum. Ada tiga macam fungsi kekuasaan terhadap hukum.

Pertama, kekuasaan merupakan sarana untuk membentuk hukum, khususnya pembentukan undang-undang (law making). Kekuasaan untuk membentuk hukum dinamakan kekuasaan legislatif (legislative power), yang merupakan kekuasaan parlemen atau badan perwakilan. Kekuasaan legislatif sebagai kekuasaan pembentuk undang-undang berasal dari pemikiran Jhon Locke dan Montesquieu.

Dalam praktek ketatanegaraan di berbagai negara, terdapat konvergensi kekuasaan pembentukan undang-undang. Pembentukan undang-undang tidak lagi menjadi monopoli parlemen, tapi kerjasama antara parlemen dan pemerintah. Bahkan kecenderungan di berbagai negara menunjukkan lebih besamya peran pemerintah dalam pembentukan undang-undang. Hal itu bisa terjadi karena pemerintah mempunyai tenaga ahli yang banyak dalam birokrasi pemerintahan guna menyiapkan konsep atau rancangan undangundang. Undang-undang merupakan produk hukum yang bersifat umum yang mengikat seluruh warganegara.
Otoritas pembentukan ketentuan hukum yang bersifat umum bukan hanya menjadi kekuasan legislatif, tapi juga menjadi wewenang badan peradilan, khususnya sistem hukum Anglo saxon yang mengakui yurisprudensi sebagai sumber hukum pokok. Yurisprudensi menjadi acuan penyelesaian kasus-kasus yang sejenis, sehingga dengan demikian juga bersifat umum. Dengan demikian, kekuasaan apa saja yang mempunyai otoritas pembentukan hukum dipengaruhi pula sistem hukumnya.

Fungsi parlemen juga mengalami perkembangan dan pergeseran. Sekarang, fungsi pokok parlemen tidak hanya sebagai badan pembuat undang-undang, namun juga perlu dilihat sebagai media komunikasi antara rakyat dan pemerintah. Dalam pemerintahan sistem parlementer ia juga berfungsi sebagai jalur rekrutmen kepemimpinan politik sekaligus sebagai badan pengelola konflik yang berkembang di masyarakat. ${ }^{35}$

Kedua, kekuasaan merupakan alat untuk menegakkan hukum. Penegakan hukum adalah suatu proses mewujudkan keinginan-keingian hukum menjadi kenyataan. Yang disebut sebagai keinginan-keinginan hukum adalah di sini tidak lain adalah pikiran-pikiran badan pembuat undang-undang yang dirumuskan dalam peraturan-peraturan hukum. ${ }^{36}$

Penegakan hukum dengan demikian bukan sekedar menerapkan-aturan-aturan hukum formal saja, tapi juga mengaitkan secara langsung aturan-aturan hukum itu

${ }^{35}$ Bambang Cipto. 1995. Dewan Penwakilan Rakyat. Rajawali. Him. 10.

${ }^{36}$ Satjipto Rahardjo. Masalah Penegakan Hukum. Tanpa tahun. Sinar Baru. Him . 24. 
dengan semangat atau spirit yang melatarbelakangi lahirnya aturan-aturan tersebut. Penegakan hukum yang sematamata menegakkan aturan formal tanpa mengaitkannya secara langsung dengan semangät yang terkandung dalam aturan akan berlangsung dengan cara yang sangat mekanistik. Padahal tuntutan penegakan hukum tidak terbatas pada pelembagaan prosedur dan mekanisme, tapi juga pada penerapan nilai-nilai substantifnya. ${ }^{37}$

Kekuasaan sebagai alat untuk menegakkan hukum merupakan otoritas negara yang merupakan otoritas tertinggi dalam struktur kemasyarakatan. Negara memiliki monopoli kekuasaan untuk menegakkan hukum karena negara merupakan organ yang disepakati masyarakat untuk mengelola kehidupan mereka. Otoritas negara untuk menegakkan hukum didistribusikan kepada institusi-institusi formal yang secara operasional melaksanakan fungsi penegakan hukum.

Otoritas negara didistribusikan kepada kepolisian untuk upaya penegakan hukum dalam pengertian mendorong masyarakat agar menaati aturan-aturan hukum atau mencegah masyarakat untuk melanggar hukum (penegakan hukum secara preventif). Pelaksanaan penegakan hukum dalam konteks ini sejalan dengan fungsi kepolisian dalam buidang keamanan guna menciptakan ketertiban dan ketenteraman masyarakat.

Di samping itu, otoritas negara untuk menegakakan hukum diberikan kepada badan peradilan (kekuasan yudikatif) untuk melakukan proses peradilan terhadap kasuskasus pelanggaran yang terjadi dalam masyarakat (penegakan hukum secara represif). Penegakan hukum secara represif bertujuan untuk mempertahankan legalitas aturan hukum dengan cara menghukum para pihak yang melanggar hukum.

Akhirnya, kekuasaan merupakan media untuk melaksanakan hukum. Adapun yang dimaksud dengan pelaksanaan hukum adalah upaya menjalankan (eksekusi) putusan pengadilan yang sudah mempunyai kekuatan hukum tetap. Putusan badan peradilan tidak akan banyak artinya bagi pengorganisasian kehidupan masyarakat jika tidak dilaksanakan secara konsekuen dan konsisten. Otoritas eksekusi merupakan kewenangan kejaksaan dan pengadilan.

Mengenai fungsi hukum terhadap kekuasaan ada empat macam. Hukum adalah media untuk melegalisasi kekuasaan. Legalisasi hukum terhadap kekuasaan berarti menetapkan keabsahan kekuasaan dari segi yuridisnya. Setiap kekuasaan yang memiliki landasan hukum secara formal memiliki legalitas. Namun yang sering menjadi masalah adalah bila kekuasaan yang legal itu adalah kekuasaan yang sewenang-wenang, tidak patut, dan tidak adil. Hal itu sebenarnya merupakan masalah legitimasi kekuasaan, yaitu pengakuan masyarakat terhadap keabsahan kekuasaan. Tulisan ini tidak akan memasuki diskursus legitimasi kekuasaan.

Dalam aturan-aturan hukum, terminologi kekuasaan muncul dalam berbagai istilah, yaitu istilah kekuasaan itu sendiri, kedaulatan, wewenang (otoritas), dan hak. Oleh karena itu, legalisasi hukum terhadap kekuasaan mencakup legalisasi terhadap kekuasaan,

${ }^{37}$ Salman Luthan. "Penegakan Hukum". Makalah Tugas S2. 1994. 
kedaulatan,wewenang, dan hak. Legalisasi kekuasan dapat diberikan kepada lembaga, jabatan, dan orang. Legalisasi kekuasaan bagi lembaga misalnya, bagi negara, lembagalembaga negara, unit-unit dalam lembagalembaga negara, unit-unit pemerintahan, dan lembaga kemasyarakatan. Legalisasi kekuasaan bagi pejabat misalnya, kewenangan presiden, kewenangan gubernur, dan kewenangan bupati. Sedangkan legalisasi hukum bagi orang adalah pemberian atau pengakuan hak bagi seseorang. Misalnya, hak milik, hak cipta, hak usaha, dan sebagainya.

Kekuasan yang dilegalisasi hukum belum tentu kekuasaan atau wewenang yang adil dan patut. Oleh karena itu, agar legalitas hukum sejalan dengan prinsip-prinsip keadilan dan kepatutan, maka legalitas kekuasaan juga harus didukung oleh legitimasi etis. Legitimasi etis kekauasaan bersandarkan pada persetujuan masyarakat terhadap kekuasaan. Dalam perspektif etika, kekuasaan dinyatakan mempunyai legitimasi bila kekuasaan itu digunakan unituk kebaikan dan keadilan masyarakat.

Fungsi hukum terhadap kekuasaan yang lain adalah untuk mengatur dan membatasi kekuasaan. Hubungan-hubungan kekuasaan dalam penyelenggaraan negara harus diatur sedemikian rupa supaya tidak menimbulkan ambiquitas dan paradoksal di antara kekuasaan-kekuasaan negara yang ada atau antara kekuasaan pejabat yang satu dengan kekuasaan pejabat yang lain. Adanya kekuasaan yang ambiquitas dan paradoks bukan hanya akan menimbulkan ketidakjelasan wewenang dan pertanggungjawabannya, tapi juga akan melahirkan ketidaksinkronan dan ketidakpastian hukum.
Untuk menghindari terjadinya ambiquitas dan paradoksal pengaturan kekuasaan, maka pengaturan kekuasaan harus dilihat dalam konteks satu sistem hukum. Pendisitribusian wewenang dalam bidang hukum tertentu harus disinkronkan dengan pengaturan wewenang dalam bidang hukum lainnya. Misalnya, harus ada sinkronisasi kewenangan antara kewenangan dalam bidang hukum tata negara dengan kewenangan dalam bidang hukum pemerintahan.

Selain fungsi melegalisasi dan mengatur kekuasaan, fungsi hukum terhadap kekuasaan yang lain adalah membatasi kekuasaan. Pembatasan kekuasaan dimaksudkan untuk menghindari terjadinya penumpukan atau sentralisasi kekuasaan pada satu tangan atau pada satu lembaga. Sentralisasi kekuasaan akan mendorong kepada otoritarianisme dalam penyelenggaraan negara dan penyalahgunaan kekuasaan (abuse of power).

Kekuasaan mempunyai kharakteristik korup. Hal ini pernah dikemukakan oleh Lord Acton dalam satu ungkapan "kekuasaan cenderung korup, dan kekuasaan mutlak korup secara mutlak pula. Pembatasan kekuasaan dapat dilakukan secara sistemik, organik dan yuridis. Menurut Bertrand Russel, sistem yang paling baik untuk mengontrol kekuasaan adalah sistem demokrasi. Demokrasi doanggap sebagai sistem terbaik bukan hanya karena adanya konsep pemisahan kekuasaan negara secara seimbang, tapi juga karena dimungkin untuk selalu mengoreksi kekuasaan tersebut.

Pembatasan kekuasaan secara organik dilakukan dengan membentuk institusiinstitusi pengawasan bagi pelaksanaan 
kekuasaan, baik yang bersifat formal maupun yang bersifat informal. Sedangkan pembatasan kekuasaan secara yuridis dilakukan melalui perumusan wewenang secara jelas mengenai lingkup wewenang itu, limitasinya dan pertanggungjawabannya.

Akhimya, fungsi hukum terhadap kekuasaan adalah untuk meminta pertanggungjawaban kekuasaan. Menurut Marion Levy, "kekuasaan selalu menyimpulkan imbangannya oleh tanggung jawab, yang berarti pertanggungjawaban dari individu-individu atau golongangolongan lainnya atas tindakan-tindakannya sendiri dan tindakan-tindakan orang-orang lain. ${ }^{38}$

Pertanggungjawaban kekuasaan dalam konteks hukum adalah untuk menjaga agar penggunaan kekuasaan sesuai dan mekanismenya dan sesuai pula dengan tujuan pemberian kekuasaan tersebut. Penyalahgunaan kekuasaan dapat dimintakan pertanggungjawaban hukum. Penyalahgunaan kekuasaan dalam bidang hukum administrasi dapat dilakukan melalui proses peradilan tata usaha negara, penyalahgunaan kekuasaan yang merugikan kepentingan seseorang atau masyarakat dapat digugat melalui peradilan perdata. Penyalahgunaan kekuasaan yang masuk kategori tindak pidana dapat dituntut secara pidana. Demikianlah pokok-pokok pemikiran tentatif mengenai hubungan dialektis hukum dan kekuasaan.

\section{Simpulan}

Berdasarkan deskripsi di atas dapat ditarik beberapa simpulan. Pertama, kekuasaan adalah suatu konsepsi hubungan sosial antara dua pihak atau dua institusi yang bersifat saling pengaruh mempengaruhi, dominatif atau eksploitatif. Kedua, hakekat hukum dapat ditinjau dari sudut otoritas yang membentuknya, substansinya dan daya kerjanya dalam mengatur masyarakat.

Dialektika hukum dan kekuasaan melahirkan dua pola hubungan, yaitu hukum identik dengan kekuasaan dan hukum tidak sama dengan kekuasaan. Pola hubungan hukum identik dengan kekuasaan merefleksikan diri dalam bentuk kedaulatan, otoritas, wewenang, dan hak. Sedangkan pola hubungan hukum tidak sama dengan kekuasaan memunculkan tiga pola hubungan: supremasi kekusaan terhadap hukum, supremasi hukum terhadap kekuasaan, dan hubungan simbiotik hukum dan kekusaan.

Hubungan simbiotik hukum dan kekuasaan melahiran hubungan fungsional di antara keduanya, kekuasaan mempunyai fungsi tertentu terhadap hukum, dan hukum juga mempunyai fungsi tertentu terhadap kekuasaan. Kekuasaan mempunyai fungsi sebagai alat untuk membentuk hukum, menegakkan hukum, dan melaksanakan hukum. Sedangkan fungsi hukum terhadap kekuasaan meliputi alat untuk melegalisasi atau menjustifikasi kekuasaan, alat untuk mengatur dan mengontrol kekuasaan, dan alat untuk mengawasi dan mewadahi pertanggungjawaban kekuasaan. 


\section{Daftar Pustaka}

Ali, Ahmad. 1996. Menguak Tabir Hukum. Jakarta: Chandra Pratama.

Apeldorn, L.J. van. 1986. Pengantar IImu Hukum. Jakarta: PT. Pradnya Paramita.

Budiman, Arief. 1996. Teori Negara, Kekuasaan dan Idiologi. Jakarta: Gramedia.

Budiman, Arief. "Bentuk Negara dan Permerataan Hasil Pembangunan". Prisma. Juli 1982.

Budiardjo, Miriam. 1991. “Aneka Pemikiran Tentang Kuasa Dan Wibawa." Jakarta: Sinar Harapan. Him. 16. Dikutip dari Max Weber. 1982. Wirtschaft und Geselschaft. Tubingen Mohr. 1982.

Cipto, Bambang. 1995. Dewan Perwakilan Rakyat. Rajawali.

Curzon, L.B. 1979. Jurisprudence. M\&E Handbook.

Hamzah, Andi. 1986. Kamus Hukum. Ghalia Indonesia.

Harian Kompas. 23 September 1999.

İswara, Fred. 1964. Pengantar IImu Politik. Dhwiwantara.

Kusumaatmadja, Mochtar. Fungsi dan Perkembangan Hukum dalam Pembangunan Nasional. Jakarta: Binacipta.

Kusnardy, Moh. dan Harmaily Jbrahim. 1988. "Hukum Tata Negara Indonesia." Pusat Studi Hukum Tata Negara Ul. HIm. 147. Dikutip dari Van Vollenhoven. Staatsrecht Oerzee. Op. Cit.
Luthan, Salman . "Penegakan Hukum". Makalah Tugas S2. 1994.

Olivecrona, Karl. 1939. Law as Fact. Copenhagen-London.

Parsons, Talcott. "The Distribution of Power in AmericanSociety." World Politics. Oktober. 1957.

- 1967. Sociological Theory and Modem Society. New York: The Free Press.

Soemardi, Soelaeman. "Pendekatan terhadap Kejahatan sebagai Suatu Fenomena Sosial." Dalam Miriam Budihardjo. "Aneka Pemikiran dalam Tentang Kuasa dan Wibawa." Dikutip dari Robert StrauszHupe. 1956. Power and Community.

Soemantri, Sri. "Masalah Kedaulatan Rakyat Berdasarkan UUD 1945." Dalam Padmo Wahyono (ed). 1984. Masalah Ketatanegaraan Indonesia Dewasa Ini. Ghalia Indonesia.

Suseno, Frans Magnis. 1988. Etika Politik. Jakarta: PT Gramedia.

Sargent, Lyman Tower. 1984. Contemporary Political /deologies. Sixth Edition. The Dorsey Press.

Rasjidi, Lili. 1988. Dasar-dasar Filsafat Hukum. Rajawali.

Rahardjo, Satjipto. Masalah Penegakan Hukum. Tanpa tahun. Sinar Baru.

Thontowi, Jawahir . "Penegakan Supremasi Hukum dalam Sistem Peradilan Indonesia." Usulan Penelitian. 